\title{
PEMANTAPAN MANAJEMEN PENDIDIKAN DI MADRASAH NABI' NUBU' KEKAIT
}

\author{
Naili Rahmawati \\ Institut Agama Islam Negeri Mataram \\ E-mail: frenzly1913@yahoo.com
}

\begin{abstract}
Abstrak: Pemantapan Manajemen Pendidikan di Madrasah Nabi' Nubu' Kekait dilakukan dengan melaksanakan kegiatan pendampingan yang bertujuan untuk mendeskripsikan implementasinya dengan melihat berbagai aspek yang ada seperti aspek kesiswaan, kurikulum, tata usaha, sarana dan prasarana, kepegawaian, keuangan dan hubungan masyarakat. Dengan tujuan ini diharapkan dapat memberikan manfaat secara teoritik sebagai wadah informasi tentang manajemen pendidikan madrasah, dan secara praktis memberikan rujukan bagi pengelola madarasah dalam mengambil kebijakan yang terkait dengan aplikasi manajemen pendidikan madrasah. Sementara itu model dan metode yang digunakan dalam kegiatan pendampingan ini antara lain: ceramah bervariasi (penyampaian materi melaui ceramah), demonstrasi dan latihan (praktek) langsung yang dipandu oleh pemateri. Sementara itu, untuk memenuhi kebutuhan data pendampingan dilakukan dengan melakukan dokumentasi terhadap data-data madrasah dan manajemennya, wawancara dengan pihak stakeholder dan observasi langsung di lapangan (obyek dampingan). Hasil kegiatan menunjukkan bahwa secara umum pengelolaan managemen telah berjalan cukup baik dan telah sesuai pengelolaan manajemen pendidikan yang sebenarnya, baik yang terkait dengan manajemen kesiswaan, kurikulum, tata usaha, sarana dan prasarana, kepegawaian, dan hubungan masyarakat.
\end{abstract}

Kata Kunci: Pemantapan, managemen Pendidikan.

\section{PENDAHULUAN}

Jumlah madrasah di Indonesia mengalami peningkatan yang cukup tajam dari tahun ke tahun, di mana pertumbuhan madrasah antara lain didukung oleh situasi tertentu yang mengkondisikan madrasah itu tumbuh dan berdiri yang dimotori oleh perseorangan atau lembaga swasta tertentu. ${ }^{55}$ Kondisi yang dimaksud antara lain adanya asumsi masyarakat bahwa madrasah dipandang mampu mengatasi problematika penyajian mata pelajaran yang dianggap tidak seimbang, yaitu antara penyajian mata pelajaran umum dengan mata pelajaran agama. ${ }^{56}$ Madrasah secara kelembagaan perlu dikembangkan sebagai respon dari

55 Abudin Nata (ed), Sejarah Pertumbuhan dan Perkembangan Lembaga-lembaga Pendidikan Islam di Indonesia, (Jakarta: Grasindo, 2001), h. 187-188

${ }^{56}$ Kemunculan madrasah di Indonesia terjadi sekitar awal abad ke-20. Meski demikian, latar belakang berdirinya madrasah tidak lepas dari dua faktor, yaitu semangat pembaharuan Islam yang berasal dari Islam pusat (Timur Tengah) dan merupakan respon pendidikan terhadap kebijakan pemerintah Hindia Belanda yang mendirikan serta mengembangkan sekolah umum 
sifat reaktif dan proaktif masyarakat dalam melihat kondisi pendidikan yang ada. Respon ini diharapkan akan membentuk pola pendidikan yang memberi corak dan arah sesuai keinginan masyarakat untuk menyeimbangkan penyajian mata pelajaran umum dan mata pelajaran agama. Upaya realisasi ini sangat membutuhkan adanya filosofi yang dijabarkan dalam strategi pengembangan pendidikan madrasah yang visioner dan lebih memberi nilai tambah strategis.

Madrasah yang semula dipandang sebagai institusi pendidikan keagamaan semata, namun saat ini telah mengalami pengkayaan peran dan fungsi. Adanya klaim madrasah sebagai "sekolah umum plus" menuntut peran dan fungsinya yang maksimal dan secara tidak langsung menjadi beban yang cukup berat bagi pengelola dalam mengelola kurikulum sekolah umum, selain juga harus memberikan materi-materi esensial keislamannya yang selama ini diajarkan. ${ }^{57}$ Beban ini semakin terasa mengingat rendahnya kualitas sumber-sumber daya yang dimiliki. Di samping sumber daya guru yang umumnya masih belum sesuai dengan kualifikasi guru mata pelajaran (khususnya pelajaran-pelajaran umum), minimnya fasilitas pembelajaran, institusi madrasah juga memiliki kendala yang sangat serius yang terkait dengan manajemen pendidikan, terutama untuk memaksimalkan dan mengembangkan sumber daya yang ada, serta kemampuan untuk mencari sumber-sumber baru yang bersifat inovatif lainnya.

Secara umum, strategi pengembangan madrasah dilakukan dengan 5 (lima) strategi pokok, yaitu untuk peningkatan layanan pendidikan, perluasan dan pemerataan kesempatan pendidikan, peningkatan mutu dan relevansi pendidikan, pengembangan sistem dan manajemen pendidikan dan pemberdayaan kelembagaan madrasah. ${ }^{58}$ Diakuinya model pendidikan madrasah di dalam perundang-undangan negara, memunculkan dualisme sistem pendidikan di Indonesia. Dualisme pendidikan di Indonesia telah menjadi dilema yang belum dapat diselesaikan. Hingga sekarang, dualisme ini tidak hanya berkenaan dengan sistem pengajarannya, tetapi juga menjurus pada keilmuannya. ${ }^{59}$ Namun, ikhtiar

tanpa memasukan pelajaran agama. Maksum, Madrasah, Sejarah dan Perkembangannya, (Jakarta: Logos Wacana Ilmu,1999), h., 82.

57 Azyumardi Azra, Paradigma baru Pendidikan Nasional, (Jakarta: Kompas, 2002), h. 71.

58 Departemen Agama, Pengembangan Madrasah, (Jakarta: Departemen Agama Press, 2004), h., 38.

59 Dualisme pendidikan Islam juga muncul dalam bidang manajerialnya, khususnya lembaga swasta. Lembaga swasta umumnya memiliki dua top manager yaitu Kepala Madrasah dan 
pengembangan madrasah ini harus tetap dilakukan, minimal strategi yang ditempuh lebih difokuskan pada upaya mencegah peserta didik agar tidak putus sekolah, lebih-lebih berupaya untuk mempertahankan mutu pendidikan agar tidak semakin menurun melalui pemantapan manajemen pendidikan madrasah.

Di Propinsi Nusa Tenggara Barat sendiri, khususnya Kabupaten Lombok Barat, jumlah madrasah yang terdiri dari lembaga Raudlatul Athfal (RA) sebanyak 56 lembaga, Madrasah Ibtidaiyyah (MI) sebanyak 95 lembaga, Madrasah Tsanawiyah (MTs) adalah 108 lembaga, dan Madrasah Aliyah (MA) sebanyak 73 lembaga. ${ }^{60}$ Potensi perkembangan jumlah madrasah di wilayah kabupaten ini menunjukkan adanya kecenderungan masyarakat terhadap kebutuhan lembaga pendidikan yang bernuansa religius selaras dengan kondisi sosial yang dominan dan kental dengan nuansa keislaman dalam aktifitas sehari-harinya.

Madarasah Nabi'Nubu' yang terletak di Desa Kekait, Kecamatan Gunungsari, Kabupaten Lombok Barat merupakan salah satu madrasah baru yang berumur kurang dari lima tahun. Madrasah yang bernaung dalam Yayasan alHusna Nahdlatul Wathan (NW) ini memiliki lembaga pendidikan formil, salah satunya adalah SMP Islam Nabi' Nubu' yang berdiri sekitar tahun 2013. Madrasah ini dalam kegiatan belajar mengajar tetap menggunakan kurikulum pendidikan nasional dan kurikulum yang dikeluarkan kementerian agama serta mengkombinasikannya dengan kurikulum lokal sebagai unsur kekhasannya.

Keberadaan Madrasah Nabi' Nubu' Kekait sebagai madrasah baru selain beberapa madrasah lama di seputaran Kecamatan Gunungsari seperti at-Tahzib Kekait ataupun al-Aziziyah Kapek yang hingga saat ini masih berjalan dan eksis jika dilihat dari pengembangan sarana dan prasarana pendukung seperti bangunan sekolah ataupun perkembangan jumlah siswa yang aktif merupakan daya tarik tersendiri untuk dikaji lebih dalam bagaimana penerapan riil manajemen pendidikannya secara keseluruhan, baik yang terkait dengan manajemen kesiswaan, kurikulum, tata usaha, sarana dan prasarana, kepegawaian, keuangan dan hubungan masyarakat. Kajian terhadap penerapan manajemen pendidikan di madrasah ini secara setidaknya akan dapat

Ketua Yayasan atau Pengurus. Praktik terjadi sering mengalami tumpang-tindih (overlepping). Rahardjo, Madrasah Sebagai The Centre of Excellence, dalam Ismail SM (ed), Dinamika Pesantren dan Madrasah, (Yogyakarta: Pustaka Pelajar, 2002), h. 228

${ }^{60}$ http://penmadlobar.madrasah.id/data-ra-madrasah. Diakses tanggal 10 Oktober 2016. 
mendeskripsikan faktor-faktor yang menjadi kendala ataupun hambatan dalam pelaksanaannya, sehingga dengan ini diharapkan dapat dicarikan solusi yang tepat untuk mengatasinya melalui pendekatan dan analisa yang komprehensif

Ensiklopedi administrasi menyebutkan bahwa manajemen mempunyai arti pengelolaan, ketatalaksanaan, pembinaan, penguasaan, pengurusan dan sebagainya. ${ }^{61}$ Dalam kajian pendidikan, manajemen pendidikan didefinisikan sebagai proses perencanaan, pengorganisasian, pengarahan dan pengendalian sumber daya pendidikan untuk mencapai tujuan pendidikan secara efektif, efisien, mandiri dan akuntabel. ${ }^{62}$ Secara umum, manajemen pendidikan meliputi:

1. Manajemen Kesiswaan, yaitu keseluruhan proses penyelenggaraan usaha kerjasama dalam bidang kesiswaan dalam rangka pencapaian tujuan-tujuan pendidikan di madrasah. ${ }^{63}$ Pengelolaan ini mencakup perncanaan kesiswaan, penerimaan siswa baru, pendataan kemajuan belajar siswa dan bimbingan serta penyuluhan bagi siswa.

2. Manajemen Kurikulum, yaitu pengelolaan yang ditujukan untuk keberhasilan kegiatan belajar mengajar secara maksimal, dengan titik berat pada usaha meningkatkan kualitas interaksi belajar mengajar. ${ }^{64}$ Manajemen kurikulum ini mencakup kegiatan perencanaan, pelaksanaan dan penilaian kurikulum.

3. Manajemen Tata Usaha, yaitu pengelolaan pengelolaan, surat menyurat mulai dari menerima, mencatat, mengolah, menyimpan, merencanakan, menggandakan dan mengirim semua keterangan yang diperlukan oleh pimpinan organisasi untuk menopang proses pengambilan keputusan oleh pimpinan organisasi di dalam pengambilan keputusan. Ruang lingkup kegiatan tata usaha adalah penerimaan dan pencatatan siswa, pengelolaan daftar hadir, dokumentasi kelas/sekolah dan laporan-laporan dan agenda dan arsip serta pengaturan proses belajar mengajar.

4. Manajemen Perbekalan/Sarana Prasarana, yaitu pengelolaan yang bertugas mengatur dan menjaga sarana dan prasarana pendidikan agar dapat

\footnotetext{
${ }^{61}$ Pariarta Weztra, Ensiklopedi Administrasi, (Jakarta: Haji Masagung, 1989), h. 263.

${ }^{62}$ Usman, Manajemen, Teori, Praktek dan Riset Pendidikan, (Jakarta: Bumi Aksara, 2009),
} h., 5.

63 Tim Dosen Jurusan Administrasi Pendidikan FIP IKIP Malang, Administrasi Pendidikan, (Malang; IKIP Malang, 1989), h. 89.

${ }^{64}$ Suharsimi Arikunto, Organisasi dan Administrasi Pendidikan Teknologi dan Kejuruan, (Jakarta: Raja Grafindo Persada, 1993), h. 58.. 
memberikan kontribusi secara optimal dan berarti pada jalannya proses pendidikan. ${ }^{65}$ Kegiatan pengelolaan sarana dan prasarana ini meliputi: perencanaan jenis dan jumlah barang, pengadaan sarana prasarana, pencatatan/inventarisasi dan penyimpanan dan pemakaian barang.

5. Manajemen Kepegawaian, yaitu segenap proses penataan yang bersangkutan dengan masalah memperoleh dan menggunakan tenaga kerja untuk dan di sekolah dengan efisien demi tercapainya tujuan yang telah ditentukan. Manajemen kepegawaian bertujuan untuk mendayagunakan tenaga kependidikan secara efektif dan efisien untuk mencapai hasil yang optimal.

6. Manajemen Keuangan, yaitu pengelolaan seluruh sumber keuangan dan pembiayaan sekolah secara garis besar dapat dikelompokkan menjadi tiga sumber yaitu: pemerintah, orang tua atau peserta didik, dan masyarakat. Pengelolaan ini meliputi perencanaan, tata usaha dan pengawasan dan pertanggungjawaban keuangan sekolah.

7. Manajemen Hubungan Masyarakat, yaitu pengelolaan jalur-jalur yang dapat ditempuh dalam hubungan madrasah dengan masyarakat antara lain ${ }^{66}$ anak atau siswa, surat-surat selebaran dan buletin sekolah, mass media (media masa), pertemuan informal, laporan kemajuan murid, kontak formal, memanfatkan sumber yang tersedia di masyarakat dan komite sekolah.

Pemantapan Manajemen Pendidikan di Madrasah Nabi' Nubu' Kekait dilakukan dengan melaksanakan kegiatan pendampingan yang bertujuan untuk mendeskripsikan implementasinya dengan melihat berbagai aspek yang ada seperti aspek kesiswaan, kurikulum, tata usaha, sarana dan prasarana, kepegawaian, keuangan dan hubungan masyarakat. Dengan tujuan ini diharapkan dapat memberikan manfaat secara teoritik sebagai wadah informasi tentang manajemen pendidikan madrasah, dan secara praktis memberikan rujukan bagi pengelola madarasah dalam mengambil kebijakan yang terkait dengan aplikasi manajemen pendidikan madrasah.

Kegiatan pendampingan terhadap madrasah di Indonesia memang bukan merupakan kegiatan yang baru, termasuk untuk menunjang kegiatan Lembaga Penelitian dan Pengabdian Masyarakat. Keberadaan hasil penelitian ataupun

\footnotetext{
${ }^{65}$ Hadari Nawawi et el, Administrasi Sekolah, (Jakarta: Ghalia Indonesia, 1986), h. 72- 87.

${ }^{66}$ Daryanto, Administrasi Pendidikan, (Jakarta: Rineka Cipta 2001), h 76.
} 
kegiatan pendampingan ini setidaknya bisa memberikan gambaran yang dapat membantu pelaksanaan kegiatan pendampingan di Madrasah Nabi' Nubu' Kekait, antara lain kegiatan Pendampingan dalam Pengembangan Media Pembelajaran Sebagai Salah Satu Upaya Untuk Memperoleh Sertifikasi Bagi Guru-Guru SMK YPKK I Sleman Yogyakarta. Kegiatan yang dilaksanakan oleh Naning Margasari dkk., Dosen Fakultas Ilmu Sosial dan Ekonomi Universitas Negeri Yogyakarta pada tahun 2009 ini secara garis besar menunjukkan keberhasilan yang ditandai dengan tercapainya target jumlah peserta pelatihan, ketercapaian tujuan pelatihan, ketercapaian target materi yang telah direncanakan dan kemampuan peserta dalam penguasaan materi pelatihan.

Sasaran (target) kegiatan pendampingan tentang Pengelolaan Manajemen Pendidikan di Madrasah Nabi' Nubu' Kekait adalah seluruh komponen (stakeholder) yang terlibat di dalam implementasi manajemen pendidikan madrasah tersebut, baik dari pengelola langsung (internal) seperti Ketua Yayasan (Pengurus), pengelola madrasah seperti Kepala Madrasah, Wakil Madrasah, Guru ataupun personalia yang lain ataupun dari pihak luar seperti tokoh masyarakat sekitar. Guna mendukung kegiatan pendampingan ini, maka dibutuhkan keikutsertaan dan pelibatan pihak terkait yang berkompeten, yaitu tenaga instruktur atau narasumber yang mumpuni, antara lain dosen atau praktisi.

Model pendekatan yang digunakan dalam kegiatan pendampingan Pengelolaan Manajemen Pendidikan di Madrasah Nabi' Nubu' Kekait ini dilakukan dengan model pendekatan klasikal dan individual. Pendekatan klasikal yang dimaksud adalah dengan memberikan teori-teori yang benar tentang manajemen pendidikan. Sementara itu, pendekatan individual dilakukan secara langsung pada saat latihan (praktek), seperti bagaimana mengembangkan kurikulum, membuat laporan keuangan, laporan kepegawaian ataupun membuat arsip dan penetaan arisparis yang baik dan benar sesuai aturan arisp dinamis.

Sementara itu model dan metode yang digunakan dalam kegiatan pendampingan ini antara lain: ceramah bervariasi (penyampaian materi melaui ceramah), demonstrasi dan latihan (praktek) langsung yang dipandu oleh pemateri. Sementara itu, untuk memenuhi kebutuhan data pendampingan dilakukan dengan melakukan dokumentasi terhadap data-data madrasah dan 
Transformasi, Vol. 12, No. 1, Januari 2016: 66-80

manajemennya, wawancara dengan pihak stakeholder dan observasi langsung di lapangan (obyek dampingan).

\section{PEMBAHASAN}

Kegiatan pendampingan pengelolaan manajemen pendidikan di Madrasah Nabi' Nubu' Kekait yang antara lain direalisasikan dengan mengadakan pelatihan (workshop) sesuai perencanaan kegiatan. Jumlah yang ikut hadir dalam pelaksanaannya sebanyak 50 orang peserta sesuai dengan target yang dicanangkan dan secara umum kegiatan tersebut dapat berjalan dengan lancar.

Permasalahan-permasalahan yang dipandang sangat mendesak untuk diatasi (termasuk di Madrasah Nabi' Nubu' Kekait) adalah masalah pengelolaan atau manajemen. Kelemahan dalam bidang ini hampir dimiliki oleh sebagian besar madrasah. Hal tersebut dikarenakan pandangan yang terbatas, lemahnya sumber daya manusia, dan minimnya pengetahuan tentang organisasi dan tata kerja di lingkungan madrasah. ${ }^{67}$

1. Manajemen Kesiswaan

Pengelola Madrasah Nabi' Nubu' Kekait dalam merencanakan perekrutan siswa baru tersebut juga telah mempertimbangan berbagai hal dan kondisi yang terkait dengan kemampuan yang dimiliki, khususnya yang terkait dengan keterbatasan ruang belajar dan sarana pendukung lainnya. Pengelola dalam melaksanakan kegiatan perekrutan ini membentuk kepanitian khusus yang dari awal sampai akhir, termasuk melakukan pendataan.

Khusus terkait dengan publikasi penerimaan siswabaru, pihak pengelola dalam menginformasikan tentang perekrutan ini hanya menerapkan cara yang sangat sederhana dengan tidak melakukan publikasi secara berlebihan, yaitu cukup hanya dengan memasang spanduk di tempat yang telah ditentukan. Pihak madrasah menilai bahwa Madrasah Nabi' Nubu' Kekait untuk saat ini lebih menfokuskan diri pada peningkatan sisi kualitas pendidikan siswa. ${ }^{68}$

${ }^{67}$ A. Wahid, Manajemen Berbasis Madrasah, Ikhtiar Menuju Madrasah Mandiri, dalam Ismail, Dinamika Pesantren dan Madrasah, (Yogyakarta: Pustaka Pelajar, 2002), h. 271.

${ }^{68}$ Model perekrutan siswa baru di Madrasah Nabi' Nubu' Kekait dilakukan dengan cara sederhana saja, bahkan selama ini informasi penerimaan siswa baru hanya melalui informasi dari orang per-orang saja. Wawancara dengan Ketua Yayasan al-Husna Madrasah Nabi' Nubu' Kekait. 
Kebijakan pengelola Madrasah Nabi' Nubu' Kekait dalam perencanaan perekrutan siswa baru ini tentunya didasarkan pada pertimbangan kondisi internal yang dimiliki (baik kekuatan ataupun kelemahan), sehingga target penerimaan siswa baru tidak dilakukan hanya untuk merekrut siswa baru sebanyak mungkin, karena hal ini akan berimbas secara umum pada kualitas pendidikan siswa sebagai akibat ketidak seimbangan antara kemampuan yang ada dengan jumlah siswa yang akan diterima. Kebijakan obyektif ini selaras dengan strategi-strategi pokok pengembangan madrasah yang ingin dicapai, khususnya dari aspek peningkatan mutu dan relevansi pendidikan. ${ }^{69}$

Tugas kepanitiaan penerimaan siswa baru dalam melakukan pendataan terhadap siswa-siswa yang diterima melalui tahapan seleksi merupakan suatu hal yang penting dan perlu diperhatikan untuk didokumentasikan. Data-data siswa baru di Madrasah Nabi' Nubu' secara umum sudah diarsipkan secara fisik, namun dalam bentuk file elektronik masih belum tertata rapi. Kondisi ini sebenarnya harus menjadi perhatian penting bagi pengelola (dalam hal ini bagian Tata Usaha dan Wakil Kepala Madrasah bidang Kesiswaan) sebagai pekerjaan rumah yang harus dibenahi. ${ }^{70}$ Karena data siswa merupakan salah satu data pokok bagi madrasah. Seringkali terjadi di mana data siswa yang tersedia di madrasah pada dasarnya telah lengkap, namun tidak tersusun secara sistematis, sehingga data tersebut tidak mampu digunakan untuk keputusan pimpinan madrasah baik keputusan yang bersifat akademik maupun administratif.

Sementara itu, pelaksanaan kegiatan pendidikan yang meliputi pengelolaan absensi dan data kemajuan belajar siswa sebagaimana lembaga pendidikan lain telah dilakukan sesuai aturan yang berlaku. Kegiatan absensi siswa di Madrasah Nabi' Nubu' Kekait umumnya dilakukan setiap hari, aspek ini cukup berpengaruh dalam pertimbangan prestasi siswa. Selain itu juga terdapat data kemajuan siswa dalam setiap semester yang berupa raport. 2004), h., 38.

69 Departemen Agama, Pengembangan Madrasah, (Jakarta: Departemen Agama Press,

70 Tata usaha mempunyai arti segenap proses kegiatan pengelolaan, surat menyurat mulai dari menerima, mencatat, mengolah, menyimpan, merencanakan, menggandakan dan mengirim semua keterangan yang diperlukan oleh pimpinan organisasi untuk menopang proses pengambilan keputusan oleh pimpinan organisasi di dalam pengambilan keputusan. Suharsimi Arikunto, op. cit, h. 97. 
Di Madrasah Nabi' Nubu' Kekait selain kegiatan regular, juga terdapat beberapa unit kegiatan siswa antara lain pramuka, dan beberapa ekstra dalam bidang olah raga, seperti futsal, volly dan lain-lain. Unit kegiatan ini merupakan wadah bagi siswa untuk mengembangkan bakat non akademiknya.

Selain itu, terkait dengan kegiatan monitoring dan evaluasi, perkembangan dan kemajuan kegiatan belajar siswa di Madrasah Nabi' Nubu' Kekait secara umum disampaikan secara periodik kepada orang tua siswa. Penyampaian hasil monitoring dan evaluasi ini dilakukan dengan memberikan undangan kepada wali siswa untuk menghadiri pertemuan untuk kegiatan tersebut. Hal ini dapat digunakan sebagai wadah bagi pengelola Madrasah Nabi' Nubu' Kekait untuk memberikan informasi kepada wali siswa tentang perkembangan peserta didik, sekaligus menjadi masukan bagi orang tua (walis siswa) untuk berpartisipasi dalam proses pendidikan dan membimbing anaknya dalam meningkatkan kegiatan belajar mengajar.

2. Manajemen Kurikulum

Penerapan kurikulum di Madrasah Nabi' Nubu' Kekait merupakan perpaduan kurikulum nasional dengan kurikulum yang ada di Departemen Agama. Hal ini dimaksudkan agar siswa mempunyai pengetahuan dan kemajuan teknologi yang telah lama memasuki dunia pendidikan. Di mana pengaruh-pengaruh negatif dari globalisasi sangat jelas dirasakan yang setidaknya dapat mematikan rasa afektif peserta didik, untuk itu agama sebagai panduan hidup tentunya dapat membendung perilaku-perilaku negatif akibat pengaruh tersebut. Oleh karenanya perlu diterapkan/disusun kerangka kurikulum yang banyak mengadopsi nilai-nilai agama dan juga kurikulum yang cocok dengan kebudayaan dan perubahan zaman. ${ }^{71}$

Untuk merespon perkembangan dan dinamika pendidikan yang ada, di Madrasah Nabi' Nubu' Kekait juga melakukan pengembangan kurikulum, khususnya aspek muatan lokal. Tentunya, tahapan pengembangan ini dilakukan setelah adanya evaluasi terhadap penerapan kurikulum tersebut. Pengembangan ini disesuaikan dengan kebutuhan masyarakat dan lingkungan setempat, hal ini dimaksudkan untuk mengimbangi kelemahan-kelemahan kurikulum sentralisasi.

\footnotetext{
${ }^{71}$ Wawancara dengan Kepala Madrasah Madrasah Nabi' Nubu' Kekait.
} 
Evaluasi dalam rangka pengembangan kurikulum ini sangat perlu dilakukan oleh kepala sekolah, pengawas sekolah, teman sejawat maupun oleh guru yang bersangkutan, hal ini untuk mengetahui seberapa jauh upaya pelaksanaan kurikulum di sekolah, juga untuk meningkatkan kemampuan profesional guru yang bersangkutan dalam pelaksanaan proses belajar mengajar di bidang studinya masing-masing. Dengan selesainya program evaluasi maka manajemen kurikulum di sekolah sudah sampai pada tahap pengawasan dan hasilnya menjadi salah satu umpan balik guna pengembangan kurikulum dimasa mendatang.

3. Manajemen Tata Usaha

Kegiatan tata usaha di Madrasah Nabi' Nubu' Kekait secara umum telah dilaksanakan. Namun, dari hasil observasi Pendamping kegiatan yang terkait dengan dokumentasi, tata kelola data, dan pengarsipan surat-surat yang masuk dan keluar belum berjalan maksimal. Kegiatan pen-dokumentasian data agaknya kurang begitu diperhatikan, sehingga madrasah tersebut menjadi kesulitan dalam mencari data-data yang dibutuhkan dalam mengambil keputusan di masa yang akan datang, seperti untuk melengkapi pemberkasan legalitas dan sebagainya. Prakteknya, dalam melaksanakan kegiatan tata usaha di Madrasah Nabi' Nubu' Kekait tidak sepenuhnya diserahkan kepada tenaga administratif melainkan tenaga edukatif dalam hal ini adalah guru turut membantu dalam setiap pekerjaan tata usaha. Selain alasan keterbatasan sumber daya (personil tata usaha), hal ini dimaksudkan agar dalam madrasah tercipta suasana gotong royong dan komunikasi antara sesama pegawai.

4. Manajemen Sarana dan Prasarana.

Hasil observasi menggambarkan bahwa sarana dan prasarana di Madrasah Nabi' Nubu' Kekait bisa dikatakan belum cukup memadai dan membutuhkan adannya upaya panambahan dari sisi kuantitas maupun upaya peremajaan dari sisi kualitas. Kondisi ini sangat terkait erat dengan kondisi pendanaan dan sumber anggaran yang bisa digunakan.

Saat ini, Madrasah Nabi' Nubu' Kekait memiliki lokal bangungan kelas sebanyak 3 ruangan, 1 ruangan digunakan untuk keperluan administrasi (perkantoran). Selain itu, sarana pendukung seperti komputer, perpustakaan masih sangat minim. Termasuk juga kelengkapan sarana dan prasarana yang 
lain masih terbatas. Namun, dengan kondisi ini pihak pengelola masih mampu memanfaatkannya secara maksimal untuk menunjang proses belajar mengajar.

Tekait dengan pengelolaan inventaris barang, tanggungjawab penyimpanan sarana dan prasaran di Madrasah dilaksanakan oleh seorang petugas perlengkapan yang dimandatkan oleh pihak Madrasah. Namun, tempat penyimpanan masih menjadi kendala, dan tentunya tidak bisa dilepaskan dari kondisi keterbatasan sebelumnya, termasuk terkait dengan pendanaan. Sehingga, barang-barang yang semestinya harus tersimpan dengan aman, terkesan agak kurang ditata, termasuk juga yang terkait dengan dokumentasi dalam bentuk pendataan inventaris yang masih ada dan digunakan belum sama sekali tersentuh.

Namun terlepas itu semua, agar proses pendidikan dapat berjalan secara efektif, maka sarana pendidikan di Madrasah Nabi' Nubu' Kekait harus berusaha dilengkapi dengan memanfaatkan kekuatan lain di dalamnya agar tertata baik, sehingga dapat dimanfaatkan semaksimal mungkin demi menunjang proses belajar mengajar yang berkualitas. Permasalahan klasik terkait dengan anggaran yang merupakan permasalahan pokok terutama lembaga swasta, kekurangan dalam hal sarana dan prasaran pendidikan tentu tidak dapat dihindari, dan pengelola di dalamnya harus melakukan pembenahan dan mencarikan solusi pemecahannya secara maksimal.

5. Manajemen Kepegawaian

Perekrutan tenaga kepegawaian oleh manajemen Madrasah Nabi' Nubu' Kekait dilaksanakan dengan model perekrutan klasik, di mana tenagatenaga kepegawain (termasuk guru) diterima dan dijaring belum dengan jalan penginformasian secara resmi. Walaupun memang dalam prakteknya penerimaan tenaga pegawai tetap dilakukan sesuai dengan kebutuhan tenaga yang dicari. Kegiatan ini sebatas pada adanya tenaga terkait yang sekiranya siap dan mampu mengemban tugas yang dibutuhkan saja. Hal ini sangat berkaitan erat dengan kondisi keuangan yang dimiliki pengurus yayasan. 
Kondisi yang terjadi ini menjadi pekerjaan rumah utama juga bagi pengelola yayasan al-Husna sebagai tempat bernaungnya Madrasah Nabi' Nubu' Kekait. Namun terlepas dari kondisi yang ada, pelaksanaan kegiatan belajar-mengajar di lembaga ini sampai dengan saat ini masih berjalan lancar dan tidak menemui kendala. Kondisi ini terlihat dari penataan data-data kepegawaian yang sudah tersedia, walaupun masih bersifat sangat sederhana.

6. Manajemen keuangan

Pengelolaan keuangan di Madrasah Nabi' Nubu' Kekait sebagaimana dijelakan oleh Ketua Yayasan al-Husna bahwa pengelolaan yang berjalan selama ini masih bersifat manual dan kekeluargaan. Dalam pengertian bahwa, perjalanan uang masuk dan uang keluar belum ditata dan dibenahi secara mapan. Kondisi pengelolaan keuangan yang ada masih belum dilakukan pencatatan secara terstruktur, hal ini disebabkan sumber keuangan yang selama ini menjadi pintu pendanaan tidak/belum jelas dan masih mengandalkan kemampuan pendiri yayasan. Namun, untuk aspek pengeluaran rutin seperti gaji atau honer pegawai ataupun pembelian kebutuhan ATK kantor misalnya, sudah dijalankan dan ditata sesuai kondisi dengan adanya laporan kegiatan tersebut.

Madrasah yang merupakan bentuk lembaga swadaya pada umumnya memang yang tidak memerlukan pertanggung jawaban keuangan yang terlalu rumit kepada penyandang dana, namun tidak menutup kemungkinan tuntutan itu bisa terjadi dari orang tua siswa ataupun dari pihak donatur misalnya. Walaupun jumlahnya relatif kecil perlu ada laporan atau penjelasan sederhana sesuai dengan prinsip-prinsip pengelolaan keuangan kepada masyarakat agar kredibilitas madrasah tersebut di mata masyarakat cukup baik.

7. Manajemen Hubungan Masyarakat

Sesuai dengan data-data yang diperoleh dari hasil wawancara, dokumentasi dan observasi di obyek dampingan, secara umum Madrasah Nabi' Nubu' Kekait telah mampu mengembangkan potensi otonom yang dimiliki, sehingga pengelola madrasah memiliki keleluasaan dan kemampuan untuk mengembangkan program-program yang sesuai dengan kebutuhan dan 
tuntutan anak didiknya, serta mampu mengelola berbagai potensi yang tersedia di madrasah maupun masyarakat sekitar madrasah untuk mencapai tujuan madrasah. Salah satunya adalah dengan mengembangkan hubungan masyarakat melalui berbagai kegiatan social dan keagamaan. Hal ini dilakukan tidak lain untuk menyerap dan mengaktualisasikan (menunjukan) kemauan, kebutuhan kepentingan masyarakat dalam program-program madrasah.

Dari beberapa bagian masyarakat, terutama pemuka (tokoh) masyarakat yang ditemui di sekitar madrasah, informasi yang diperoleh memberikan gambaran bahwa Madrasah Nabi Nubu' Kekait baik melalui pengurus yayasan ataupun pengelola madrasah selalu melibatkan anggota masyarakat dalam berbagai kegiatannya, terutama untuk pembangunan fisik madrasah seperti bangunan kelas dan sebagainya.

Dengan melihat kondisi ini, dapat disimpulkan bahwa Madrasah Nabi Nubu' Kekait dalam menjalankan kegiatan pendidikannya secara langsung telah menerapkan manajemen pendidikan khususnya yang terkait dengan hubungan masyarakat. Kerjasama Madrasah dan masyarakat sangat penting untuk meningkatkan keterlibatan, kepedulian, kepemilikan dan dukungan operasional masyarakat terhadap madrasah baik moral maupun finansial. Hubungan madrasah dengan masyarakat pada hakikatnya merupakan sarana yang sangat berperan dalam membina dan mengembangkan pertumbuhan pribadi peserta didik di madrasah. Hubungan yang harmonis semakin dirasakan pentingnya pada masyarakat yang telah menyadari dan memahami pentingnya pendidikan bagi anak-anaknya.

\section{PENUTUP}

Implementasi manajemen pendidikan di Madrasah Nabi' Nubu' Kekait secara umum telah berjalan cukup baik dan telah sesuai pengelolaan manajemen pendidikan yang sebenarnya, baik yang terkait dengan manajemen kesiswaan, kurikulum, tata usaha, sarana dan prasarana, kepegawaian, dan hubungan masyarakat. 
Namun, beberapa hal yang perlu dibenahi dan mendapat perhatian serius baik dari pengelola yayasan dan pengelola madrasah adalah pengelolaan keuangan yang masih jauh dari penerapan manajemen yang seharusnya, yakni bagaimana mengelola dana masuk dan dana keluar termasuk keharusan adanya pelaporan keuangan yang jelas untuk menciptakan pengelolaan manajemen yang profesional, agar lembaga yang dikelola dapat dipertanggungjawabkan sebaga lembaga yang transparan dan akuntabel sesuai tuntutan dan harapan masyarakat sebagai bagian stakeholder dari Madrasah Nabi' Nubu' Kekait.

Untuk itu, sebagai bahan rekomendasi, maka dibutuhkan adanya kegiatan lanjutan berupa pelatihan teknis sejenis yang diselenggarakan secara periodik, sehingga target atau tujuan pendampingan yang belum tuntas sebelumnya dapat tercapai sesuai harapan dalam konteks pengabdian kepada masyarakat. Selain itu, waktu pelaksanaan kegiatan pengabdian perlu ditambah agar tujuan kegiatan dapat tercapai maksimal, dengan konsekuensi adanya penambahan biaya pelaksanaan secara proporsional sesuai kondisi dampingan pengabdian kepada masyarakat.

\section{DAFTAR PUSTAKA}

Arikunto, Suharsimi, Organisasi dan Administrasi Pendidikan Teknologi dan Kejuruan, Jakarta: Raja Grafindo Persada, 1993.

Azra, Azyumardi, Paradigma baru Pendidikan Nasional, Jakarta: Kompas, 2002.

Daryanto, Administrasi Pendidikan, Jakarta: Rineka Cipta, 2001.

Departemen Agama, Pengembangan Madrasah, Jakarta: Departemen Agama Press, 2004.

Fathurahman, P., dkk., Pengembangan Pendidikan Karakter, Bandung: Rieka Aditama, 2013,

Maksum, Madrasah, Sejarah dan Perkembangannya, Jakarta: Logos Wacana Ilmu, 1999 
Transformasi, Vol. 12, No. 1, Januari 2016: 66-80

Nata, Abudin, (ed), Sejarah Pertumbuhan dan Perkembangan Lembaga-lembaga Pendidikan Islam di Indonesia, Jakarta: Grasindo, 2001.

Nawawi, Hadari et.al, Administrasi Sekolah, Jakarta: Ghalia Indonesia, 1986. Administrasi Pendidikan, Jakarta Toko Gunung Agung, 1996.

Nurhadi, Muljani A., Administrasi Pendidikan di Sekolah, Yogyakarta: Andi Offset, 1996.

Rahardjo, Madrasah Sebagai The Centre of Excellence, dalam Ismail SM (ed), Dinamika Pesantren dan Madrasah, Yogyakarta: Pustaka Pelajar, 2002.

Sagala, Syaeful, Manajemen Berbasis Sekolah dan Masyarakat, Jakarta: Nimas Multima, 2004.

Subrato, B. Suryo, Administrasi Disekolah, Jakarta: Bina Aksara, 1988.

Sutisna, Oteng, Administrasi Pendidikan, Bandung: Angkasa, 1989.

Tim Dosen Jurusan Administrasi Pendidikan FIP IKIP Malang, Administrasi Pendidikan, Malang, IKIP Malang, 1989.

Undang-Undang RI No. 20 Tahun 2003 Tentang Sistem Pendidikan Nasional, (Sisdiknas) Bandung: Fokusmedia, 2003.

Usman, Manajemen, Teori, Praktek dan Riset Pendidikan, Jakarta: Bumi Aksara, , 2009.

Wahid, A. Manajemen Berbasis Madrasah, Ikhtiar Menuju Madrasah Mandiri, dalam Ismail, Dinamika Pesantren dan Madrasah, Yogyakarta: Pustaka Pelajar, 2002.

Weztra, Pariarta, Ensiklopedi Administrasi, Jakarta Haji Masagung, 1989. 